\title{
13.4 Dictionaries of Language Difficulties
}

\begin{abstract}
This article provides an overview of the history and the current situation of the so-called dictionaries of doubts and difficulties. These instruments are meant to address the speakers' "insecurity" concerning specific aspects of the Portuguese language. This concerns both the European and Brazilian norm. The current dictionaries of difficulties will be contextualized within the wider Lusophone tradition. By doing so, the article will present a critical panorama of the most important dictionaries of difficulties published at the end of the $20^{\text {th }}$ and the beginning of the $21^{\text {st }}$ century. Emphasis will be put on how these instruments reflect different normative attitudes and discursive strategies vis-à-vis the diversity of usages and language change.
\end{abstract}

Keywords: Portuguese, linguistic difficulty, linguistic insecurity, dictionaries of language difficulties, style books, standardization, implementation, modernization, normative discourse, pluricentricity

\section{Introduction}

An awareness of the variability of the language and the feeling of "insecurity" (cf. Francard 1997) regarding the "correct" or "good" use of Portuguese first emerged right after the beginnings of the metalinguistic tradition. Testimony thereof is given by grammarians and other authors who saw themselves confronted both with the variation of spoken language and the necessity of a written standard language (Oliveira 1536; Barros 1540; Gândavo 1574; Leão 1576; cf. Santos 2006). Debates concerned the selection of a social and geographical variety that could serve as the basis of that standard and as a model for orthography (Feijó 1734; Verney 1746; Monte Carmelo 1767). Later on, language became the object of a puristic attitude (Leite 1997), which became obvious in the $17^{\text {th }}$ century due to contact with other languages. Purism is a manifestation of metalinguistic thought (Delveroudi/ Moschonas 2003) according to Houaiss/Villar $(2015,3195)$ and is defined by the aprioristic rejection of "toda transformação de caráter regencial, sintático ou empréstimo de estrangeirismos, fixando arbitrariamente determinado momento histórico como depositário atemporal da correção linguística”. In the first dialogue of his Corte na Aldeia (1991 [1619]), Francisco Rodrigues Lobo stated accordingly that his contemporaries used their mother tongue "mais remendada do que capa de pedinte" (1991 [1619], 85). The influence of borrowings, especially from Spanish, started to be seen as a threat. This was a topos that would be the leitmotiv of the dictionaries of doubts and difficulties even though, during the $19^{\text {th }}$ and the first half of the 